\title{
Polska i szwedzka epika propagandowa w pierwszej polowie XVII wieku
}

Jakub Niedźwiedź 
utPDS Seria XII 2006

\section{Jakub Niedźwiedź}

\section{Polska i szwedzka epika propagandowa w pierwszej połowie XVII wieku}

$\mathrm{L}$ atryna na galeonie „Vasa”, zbudowanym w 1628 flagowym okręcie marynarki szwedzkiej, tak jak w innych tego typu jednostkach, znajdowala się na jego dziobie. Można ją dziś obejrzeć z bliska: wylowiony w latach sześćdziesiątych XX wieku wrak okrętu stanowi jedną z największych atrakcji turystycznych Sztokholmu. Sicdemnastowieczni cieśle oslonili dolną część owego miejsca sekretnego plaskorzeźbani. Wyobrażono na nich mężczyznę na czworakach, z sumiastymi wąsami, podgoloną czupryną i w długiej szacie. Aby nie było wątpliwości, kogo symbolizuje ta postać, autorzy wystawy powiesili obok reprodukcje powstałego mniej wiçcej w tym sanym czasie co plaskorzézba portretu, przedstawiającego wojewodę ruskiego Jakuba Sobieskiego. Ten sam sumiasty wąs, strój, fryzura - poza tylko jakby nieco inna.

„Vasa” w momencic wodowania byl najwiçkszym okrętem wojennym na Baltyku. Jego znaczenie mialo się jednak zasadzać nie tylko na sile armat, ale równicż na smukłej sylwetce, olbrzymich żaglach, a także na programie ikonograficznym, który został wpisany w ten okręt: alegorie i znaki heraldyczne na rufie były miejscem chwały króla szwedzkiego, dziób mial służyć hańbic Polaków. Caly okręt, jego wartość bojowa, jak i walory symboliczne oraz ideologiczne brały udzial w wojnie z Rzecząpospolitą, a zołnierz szwedzki nawet w wychodku przyczyuial się do zwycięstw Gustawa Adolfa.

Przez pierwsze kilkadziesiąt lat konfliktu o dominimu Maris Baltici Szwedzi mało dbali o ksztaltowanie swojego wizerunku w opinii wlasnej i międzynarodowej. W zmaganiach militarnych o twierdze inflanckie obie strony odnosily sukcesy i porazki, jednak w dziedzinie propagandy Szwedzi znajdowali się przez długi czas w defensywie, wlaściwie oddając pole: zdawać by się mogło, że nic zauważali potrzcby angażowania siç w wojnç propagandową. Nawet jeśli pojawialy siç inspirowane przez Szwedów pisma, mialy one niewielki zasiçg, ograniczający się do wąskiego grona dyplomatów curopejskich. (ilówną przeszkodą bylo zapewne 
to, że w czasie pierwszej wojny między Zygmuntem Wazą a Karolem Sudermańskim król szwedzki nie miał odpowiedniej kadry: humanistów, którzy mogliby pisać teksty propagandowe: typografów, którzy by je drukowali; ksiçgarzy, którzy zadbaliby o ich dystrybucję, wreszcie polityków i urzędników, którzy rozumicliby konicczność ich pisania, drukowania i rozpowszechniania.

Dopiero w pierwszej połowie lat dwudziestych XVII wieku Szwedzi w większym stopniu docenili rolę propagandy, czego wyrazem było zarówno wodowanie reprezentacyjnego galeonu „Vasa”, jak i liczne a uszczypliwe wobec Sarmatów publikacje. Tym właśnie utworom, polskim i szwedzkim, bę̧dzie poświęcony nój artykul ${ }^{1}$. Temat jest bardzo rozległy, gdyz w XVII wieku po obu stronach powstała ogromna liczba tekstów, która w niewielkim stopniu byla przedmiotem zainteresowań historyków literatury. Ograniczę się więc do ukazania kilku najważniejszych zagadnień, które powinny zostać w przyszłości potraktowane szerzej.

Na początku XVIl wieku możliwości propagandowe literatury szwedzkiej byly bardzo skromne, jeśli siç je porówna z liczbą podobnych tekstów opublikowanych przez Polaków i Litwinów. Nowożytna literatura propagandowa w Polsce zaczęła sic̨ na początku XVI wicku, kiedy pisali przedstawiciele pokolenia humanistów urodzonych w latach osiemdziesiątych poprzedniego stulecia, między innymi Jan Dantyszek, Jan z Wiślicy, Mikolaj I Iussowski i Andrzej Krzycki. Ich ukladane po łacinic poezje z jednej strony informowaly czytelników z innych krajów o „europejskości” Polski i Litwy, z drugiej zaś przedstawialy militarne dokonania Polaków, zwłaszcza w wojnach z Moskwą i Tatarami². Pobitwie pod Orszą w 1514 wyslanodo Rzymu kilku jeńców oraz epinicjon Jana Dantyszka ${ }^{3}$. Wiersze te byly jakby uzupełnieniem dziel historyków i chorografów dzialających w ,Sarmacyi Europskiej”.

W późniejszym okresie podobnycl wierszy i poematów powstawało więcej, prawdziwy ich wysyp nastąpit w latach osiemdziesiątych XVI wieku, zarówno po lacinie, jak i po polsku. Inspiracje były rozmaite i wyliczenie ich wszystkich jest trudne. Nalezą do nich między innymi wzrost poczucia świadomości obywatelskiej i narodowej, zwycięskie zmagania z Moskwą, autorytet arcypoety Wergiliusza, rozwijający się mecenat. Teksty, które zaliczylibyśmy do tej grupy, nawet jeśli powstawały w Małopolsce i drukowano je w Krakowie, były związane przede wszystkim z Litwą oraz Inflantami, czy to przez postać bolıatera, mecenasa, czy przez miejsce powstania i publikacji. Dość wymienić poematy Andrzeja Rymszy Deketeros akroama, Jana Kochanowskiego Jezde do Moskn'y, Jana Radwana Radirilias - utwory pozostające w kręgu mecenatu Radziwilłowskiego, a także Stephaneis najznacznicjszego i najpłodniejszego pocty tworzącego w ówczesnej Rydze, Daniela Hermamna.

Ten ostatni utwór i autor powimni nas szczególnie zaciekawić. Hermann (1543-1601) i inni humaniści ryscy w kilkudziesięciu drukach wychwalali kanclerza i hetmana. Zamoyski,

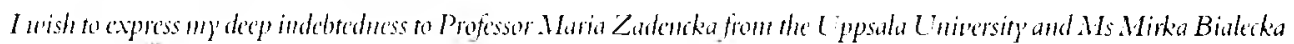

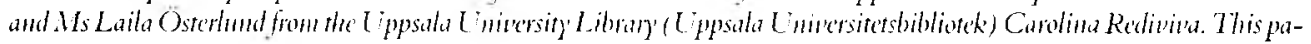

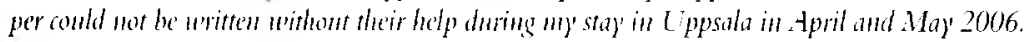

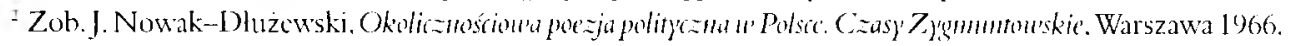

${ }^{3}$ Zob. J. Dantyszek, Camima. wyd. S. Skimina, Kraków 1950.
} 
będący administratorem Inflant, imponowat poctom z Rygi nic tylko ze względu na wladzę cywilną i wojskową, jaką sprawowal nad nimi, ale też ze wzgględı na swoje padewskie wyksztatcenie. W tym czasie zreformowano gimmazjum ryskie na wzór Akademii Zanojskiej, zaś w 1588 roku powstała w mieścic pierwsza drukarnia Mikołaja Möllera, typografa dzialającego w Rydze do roku $1625^{\dagger}$. Nie powinno dziwić, ze pierwszym opublikowanym tam utworem jest łaciński panegiryk ku czci Zygmunta III Wazy oraz Jana Zamoyskiego ${ }^{5}$. Kiedy protestanccy mieszkańcy Rygi modernizowali swoje gimnazjum miejskie, zaraz po sąsiedzku jezuici założyli swoje wlasne kolegium". Mówiąc krótko, pod panowaniem polskim w mieście na dobre rozkwitla kultura humanistyczna, co było nic bez znaczenia dla majacej lada moment wybuchnąć wojny polsko-szwedzkiej.

Na przełomie XVI i XVII wicku w rejonic dzialan zbrojnych istniało zatem kilka dużych centrów humanistycznych, z których najwiçkszą rolę w wojnie propagandowej mialy odégrać Wilno i Ryga, okresowo równiez Gdańsk. W tym czasie glównym ośrodkiem kultury humanistycznej w Szwecji była Uppsala, jednak jeszcze przez kilkadziesiąt lat nie mogla ona konkurować z ośrodkani Inflant, Litwy i Prus.

Powybuchu konfliktu zaczęto wydawać najrozmaitsze broszury polityczne, awizy lub inne wezesne formy gazet, w których przedstawiano racje Zygmumta III i Karola Supermańskiego, a walory propagandowe lączyły się z informacyjnymi. Należą do nich na przyklad listy obu wladców opublikowane w Cidansku ${ }^{7}$ lub listy Jana Karola Chodkiewicza". Językiem, w którym wydawano tego rodzaju utwory, była lacina, nieco rzadziej niemiecki, priwie wcale nie używano polszczyzny i szwedzkicgo.

Żywotność prozatorskich awizów była jednak dość krótka, natomiast za trwalsze i bardziej wartościowe uważano „awizy” wierszowane lub w ogóle poematy relacjonujące przebieg wydarzeń. Z racji ich poetyckiego ksztaltu do wierszy możma bylo wracać jeszcze przez dlugi czas, kiedy opisywane wydarzenia dawno juz przebrzmialy. Teksty te miały zasadniczo cztery funkcje: informowaly o bieżących lub niedawno minionych wydarzeniach; kierowaly sposobem interpretacji tych wydarzeń; wychwalały ich bohatera (wodza, whadce lub rzadziej jakąś grupę, na przyktad naród); dostarczały czytelnikowi doznań estetycznych. Posługując

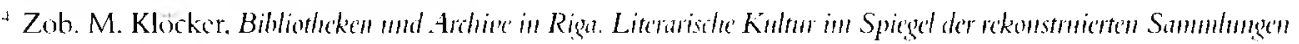

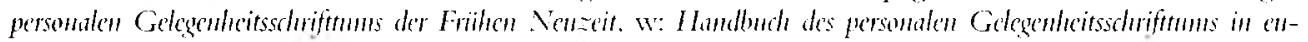

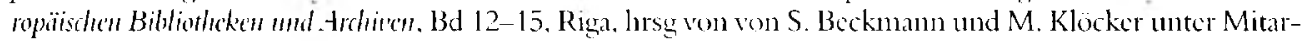
beit von \$. Anders, llideshein-Zurich-New York 21n)t. Olnns-Weideman. s. 25-30: Feodilà Rìna, red. T. Zeids, Riga 1978, s. 170.

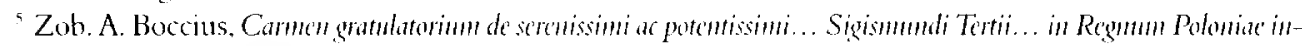
gressu... scriptum. Ad ... Joammen Zamoissinm.... Rigac, excud. Nic. Mollints, 1588.

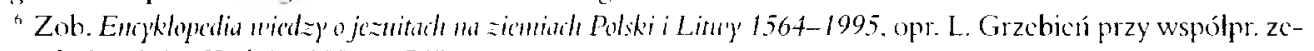
spolu jezuitów. Kraków 1996, s. 588.

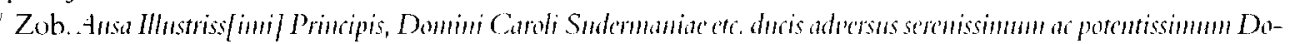

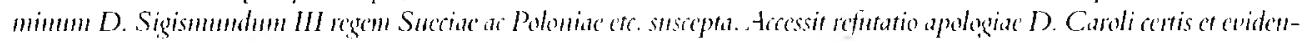
tib/us/rationib/us/ suffulta. Siripra ct pullicata cx mandato S. R. Maicstatis propric. Dantisci, in off. typogr. Iac. Rhodi, 1598.

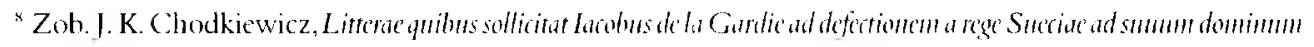
dic 24. Martii 1613.
} 
się dawną teorią retoryczną, możemy zatem mówić of funkcjach docere, permovere i delectare, tyle ze w odniesieniu do tego typu literatury wymienione funkcje nabieraly nieco innego znaczenia niż te podawane w podręcznikach sztuki wymowy. W każdym razie czytelnicy owych tekstów rozpoznawali epicki lub jakiś inny retoryczny model fabularyzacji”, toteż bez powazniejszych kłopotów przychodziło im zrozumieć ustanowiony przez autora przebieg wydarzeń. Inna rzecz byla z zaakceptowaniem interpretacji zdarzeń, którą teksty te niosly ze sobą.

Poetycka akcja propagandowa mogła być skierowana w kilku kierunkach. Kiedy myślimy o odbiorcach tych wierszy, w pierwszej kolejności bierzemy pod uwage audytorium zagraniczne, które autorzy tekstów pragnęli sobic zjednać. Ale nic jest to jedyna grupa czytelników. Druga, nic mniej ważną, są wrogowie, którzy mają się dowiedzieć, jacy są niedobrzy. Po trzecie wreszcie, pisze się takie wiersze dla swoich whasnych, domowych czytelników i dla wzmocnienia samych sicbic. Ze wszystkimi trzema typami odbiorców spotykamy się w wierszach z okresu wojny polsko-szwedzkiej.

Za preludium możc być uznany dłuższy wiersz wydrukowany w Rydze na samym początku XVII wieku. Kiedy oddziały szwedzkie zaczęły w 1601 zajmować Inflanty i niebezpiecznic zbliżać się do Rygi, jeszcze w tym samym roku, roku swojej śmierci, Daniel I Iermann napisat i wydal ułożony w dystyclu elegijnym utwór Livoniae afflictae... suplicatio ${ }^{1 "}$, dedykowany Zygmuntowi III. Jeszcze dziś, po czterech stuleciach, czuć w tym wierszu grozę zblizającej się wojny, której mieszkańcy Rygi dwadzieścia lat wcześniej dotkliwie doświadczali. Kilkustronicowy druczek został ozdobiony stcmmatem wyobrazającym Orla Białcgo, który to utwór pełnil funkcję captatio bene'olentiae wobec mieszkańców Korony. W poemacie stary poeta prosi króla i stany Rzeczypospolitej o skuteczną ponoc, kreśląc obraz osannotnionych Inflantczyków: „Garstka nas daremnic walczy na wątpliwym placu”.

W 1603 administratorem Inflant został Jan Karol Chodkiewicz, który przede wszystkim dzięki swoim zwycięstwom, ale też dzięki mecenatowi i rozległym koneksjom z jezuitami zyskal pozycję głównego literackiego bohatera wojny Rzeczypospolitej ze Szwecją: stal siç nim na długo przed wojuą chocimską, z którą dziś jest przeważnie kojarzony. Kiedy w 1605 rozbil armię Karola IX pod Kircholmem i zniósł oblężenie Rygi, rozeszly się awizy o tym wydarzeniu, przynosząc mu slawę w catej Europic, a jednocześnie ntwierdzając pretensje Zygmunta III do Inflant.

Dwa poematy o bitwie kircholmskicj są reprezentatywne dla „polskicj” literatury propagandowej z czasów wojen toczonych ze Szwecją w latach 1600-1611". Wywodzą się one

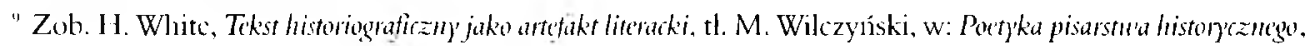
red. E. Domańska, M. Wilczyński, Kraków 2000). s. $78-108$.

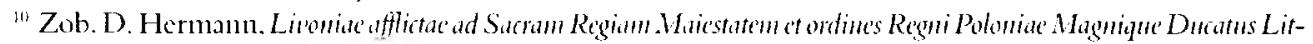
huaniae etr. supplicatio. Rigac Livonum. ex oft. typogr. Nic. Mollini. 1001.

${ }^{11}$ Nic są to oczywiście dwa jedyne utwory o bitwie kircholmskicj. Niekiedy poświçcano jej fragmenty więtszych utworow np. obszerne pisze o niej Szymon Szymonowic w pocmacie Trophaewm Stanishai Zolkevii Scythis cuesis fingutis wydanym w Zamościu w 1606. Por. J. Pelc. Wstep do: Sz. Szymonowic, Sielanki oraz pozostate wicrsze polskic. opr. J. Pek. Wroclaw 2000 (BN I 182), s. XLIII.
} 
7. dwóch różnych środowisk: z jezuickiej Akademii Wileńskiej oraz spośród humanistów ryskich skupionych wokół gimnazjum protestanckiego.

Lepicj znanym utworem przedstawiającym zwycięstwo Chodkiewicza jest Carolonadia napisana przez wileńskicgo jezuitę Wawrzynica Bojera $(1561-1619)^{12}$. Liczący blisko dwa tysiące heksametrycznych wersów poemat cpicki wydanow Wilnic rok po bitwie. Ciekawostką może być, że Bojer pochodził ze Sztokholmı. Carolonadria wypehnia wszystkie wymicnione wyżej funkcje pocmatów epickich opisujących wspólczesne wojny. Znajdujemy w niej chronologiczne przedstawienie wydarzeń, ich interpretację w świetle korzystnym dla Polaków i katolików, panegiryzm i daleko posuniętą estetyzację. Poematowi towarzyszą mniejsze pieśni i epigramaty, co było rzeczą zwykłą w tego rodzaju przedsięwzięciach. Ze względu na poziom artystyczny, znaczenic i postać autora utwór ten od jakiegoś czasu wzbudza słuszne zainteresowanie badaczy polskich i litewskich, i być może doczeka się przekladów oraz reedycji.

Jeszcze w 1605 roku wyszedł spod prasy Mikołaja Mollina drugi interesujący nas poemat pod tytulem I ictoria quam... Sigismundi III... prope Kercholmum ... obtimuernut ${ }^{13}$. Jego autorem jest miejscowy humanista i absolwent uniwersytetu w Wittenberdze, Basilius Plinius (ok. 1570-16(05). I ítoria jest krótsza od Carolomadhii i w większym stopniu przypomina diariusz, w marginaliach podane zostały w porządku clıronologicznym daty wydarzerí przedstawianych w heksametrycznym poemacie. Trzon poematu stanowi relacja z sierpnia i września 1605 roku.

Faktografia jest w utworze równie ważna co interpretacja. Pod tym względem poemat przypomina inne poematy lacińskie, które można zaliczyć do grupy tekstów opisujących współcześnie toczące się wojny. Interpretacji dokonywano przy pomocy powszechnie rozumianego kodı, toposów i zabiegów imitacyjnych zaczerpniętych z poezji rzymskiej, przede wszystkinn z epiki. Odbywająca się w ten sposób fabularyzacja wydarzeń historycznych byla rozumiana jako bardzo skuteczna w rozprzestrzenianiu ideologii, ponieważ kod ten był zrozumialy przez wszystkich ludzi zanurzonych w kulturze laciniskiej (Latinitas), czyli przez wszystkich wykształconych ludzi.

Autorzy ıtworów epickich, którzy mieli możliwość rozwinięcia tematu, mocno zaznaczali bezprawność działań Szwedów: po pierwsze, Zygnnunt III stale nazywany jest królem

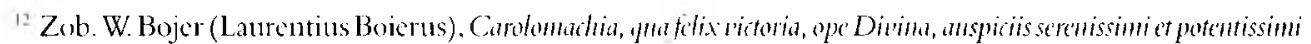

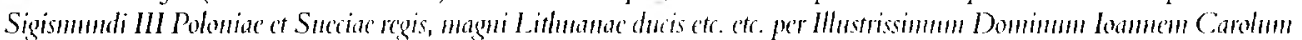

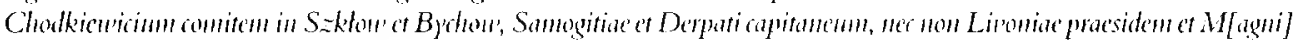

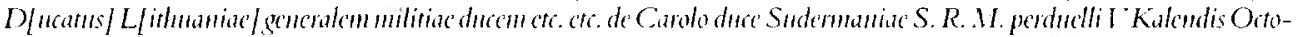

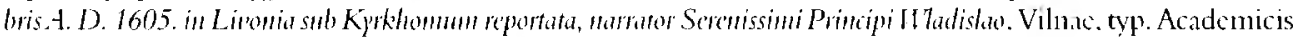
S. I. Th. Levicki, I6106. Na karcic tytulowej jako autor podany zostal Krzysztof Zawisza (. „Ch Chistophoro Zan'isza in alma I ilmensi Aademia Socictatis Iesu studioso"). który podpisal siç też pod listeundedykacyjnym. Rzcczywistym autorem jest jednak Bojer, który „uzyczyl” swojegro poematu znacznic jszej osobic. W XVI-XVIII w. na Litwic często siç zdarzało w relacjach klicntarnych, zc jezuici pisali utwory w imicniu swoich patronów

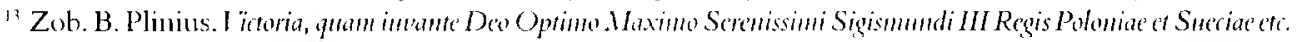

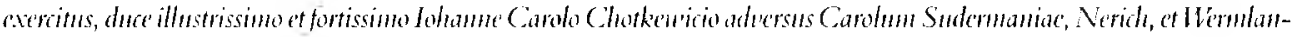

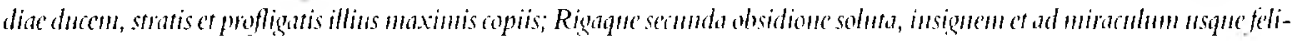

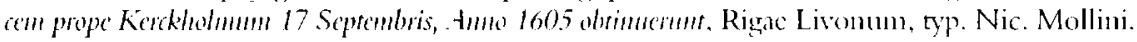


Szwecji, zaś Karol IX po prostu Karolem Sudermanískim; po drugie, podkreślane sa prawa Rzeczypospolitej do Inflant - w częściach wstępnych obu poematów poeci piszą o uwolnieniu Inflant spod okupacji moskiewskiej przez Stefana Batorego. Stąd, poza układami jeszcze z czasów Zygmunta Augusta, ma się wywodzić prawo królów polskich do administrowania tymi ziemiami. Bezprawność pociągała za sobą konsekwencje metafizyczne. Łamanie prawa jest w tym wypadku lamaniem porządku ustalonego przez Boga, a zatem Bóg, ze względów metryczno-ideowych nazywany dość często Jehową, interweniıje, karzạc wiarołomnego Sudermańczyka.

Poemat Bojera przyćmil wszystkie inne utwory sławiące zwycięstwa hetmana litewskiego: Bazylego Pliniusza, Dionizego Fabriciusal ${ }^{1+}$ i Filipa Mittendorfa ${ }^{15}$, aczkolwiek ich znaczenie propagandowe bynajmnicj nie bylo muiejsze. Duża część spośród tych, które powstaly w Rydze, miała w gruncie rzeczy wymowę bardziej niekorzystną dla Szwedów w porównaniu z tymi, które ukladano w Wilnie. Carolonadia zostata napisana przez jezuitę, więc wymowa utworu musiała być katolicka - Chodkiewicz osiągnął zwycięstwo dzięki wstawiennictwu Matki Boskiej oraz patronów Wilna, świętych Stanisława i Kazimierza "'. Autorzy tworzący w Rydze byli wszakze luteranami, więc ich świadectwo w oczach protestanckich czytelników z basenu Morza Baltyckicgo musiało wydawać się bardziej wiarygodne. W ich tekstach wymiar wyznaniowy zwycięstwa zostal zredukowany do minimum, choć sporo micjsca poświçcano pomocy Boga. W utworach protestantów częćciej niż u katolików przytacza się przyklady ze Starego Testamentu, jako znak interwencji Bogga.

Kwestie etyczne sajednym z konstytutywnych elementów tych poematów. Rozpoznanie i ocena tego, co dobre i zle, obejmuje wszystkie wymienione wcześnicj warstwy utworu, podlega jej bowiem sposób przedstawienia wydarzeń, ich interpretacja, przedstawienie bohaterów, zabiegi inwencyjne i elokncyjne, a niekicdy nawet forma wiersza. Na przykład wybór formy epickiej domaga się odpowiedniego uksztaltowania świata przedstawionego, w tym równicż umieszczenia znaków "plus” po stronie głównego bohatera utworu i „minus” przy postaciach i poczynaniaclı wrogów. Niekiedy wydobywa się pewne elementy świata przedstawionego i naświetla przy ponocy odpowiednich zabiegów retorycznych lub fabularnych.

Basilius Plinius pisze zatem o oddzialach niemicckich stanowiących część armii Karola Sudermańskiego. Fakt militarny sam w sobie bylby obojętny, jednak poeta korzysta z homonimii słowa Germamu, które można rozumiéc jako 'brat' oraz jako 'Niemiec'. Najeźdźcami niemieckich mieszczan ryskich są zatem ich niemieccy bracia z Rzeszy, którzy zaciągnęli się

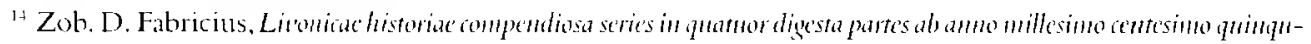

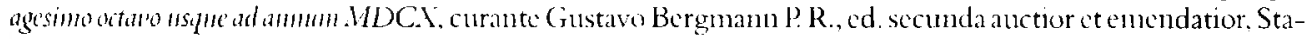
n110 Ruisiendi. 1795.

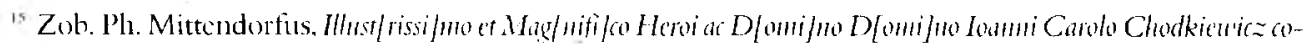

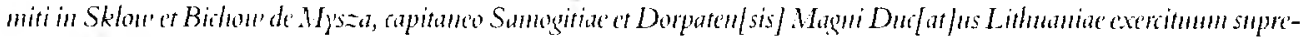

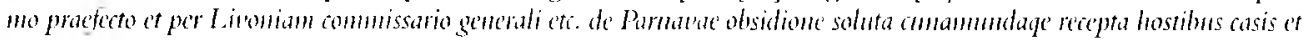
profligatis Riga glatmatur. Rigac Livonum, typ. Nic. Mollini. 1609.

ir Zob. W. Bojer, op. cit. k. 132 2 -B 3. 
pod rozkazy króla Szwecji, wobec czego zashıgıją na zdecydowane potępienie ${ }^{17}$. Jak widać, każdy, nawet najdrobnicjszy fragment zdarzeń mógł w tekście zostać tak uformowany, aby słuzył rozumieniu tych wydarzeni zgodnym z intencjani pisarza. Nie inaczej postępowali autorzy pracujący ku chwale króla Szwecji.

Dopiero za czasów Gustawa Adolfa i drugiej wojny polsko-szwedzkiej pojawily się na większą skalę utwory przedstawiające racje Szwedów, a i to dopiero po zdobyciu Rygi w 1622. Z powodu wojen z Moskwą a później Turcja Rzeczpospolita w mnicjszym stopniu angażowała się w obronę swoich interesów w Inflantach, zarówno na polu militarnym, jak i w dziele propagandowym. Nie lepicj było i w późnicjszyın okresie, kiedy wojna przeniosła się na teren Prus. Szwedzka machina propagandowa ruzkręcila się zaś na dobre po zaangażowaniu się Gustawa Adolfa w wojnę trzydziestoletnią. W tych zmaganiach propagandowych wsparli króla szwedzkiego protestanci z całcj Europy, jednocześnie jednak wojna polsko-szwedzka zeszla na drugi plan, a zaszczytne miano głównego przeciwnika zyskali Habsburgowie.

Sukcesy militarne Gustawa Adolfa wspomogły jego muzę propagandową nie tylko dzięki dostarczeniu jej tematów, ale również poetów i drukarń. Wydaje się, że kluczowym monentem było zajęcie Rygi, której poeci, jako najbardziej zainteresowani, najczęściej obok poetów gdańskich pisali o toczącej się wojuie. Pisarze na słuzbie króla polskiego z imuych miast niż Ryga i Crdańsk raczej interesowali się wojnanı z Turcją i Moskwą. Najwyraźniej widać to na początku lat trzydziestych, kiedy na terenie Rzeczypospolitej pisze siç wiersze niemal wylącznic o zwyciçstwic pod Smolenískicm, ignorując wydarzenia w Prusach oraz Inflantach. Na przykład wileńscy jezuici po Carolonarhii juz się nie zdobyli na zaden utwór o podobnych rozmiarach. Można przypuszczać, ze powodem tego stanu rzeczy byly nie tyle niepowodzenia na froncie intlanckim, bo sukcesy też się zdarzały, ale wiçksze zainteresowanie sprawami moskiewskimi.

W latach dwudziestych i trzydziestych XVIl wieku ukazalo się wicle utworów sławiących Gustawa Adolfa. Autorami tych tekstów byli poeci i prozaicy różnej narodowości, glównie protestanci, którzy upatrywali w królu szwedzkinn swojego wybawiciela. Najwięcej publikowano ich po zaangażowaniu się Szwedów w wojnç trzydziestoletnią. Powstawały dzieła zarówno historyczne, jak i liryczne i epickie. Wiçkszość z nich stworzyli lnumaniści, którzy nie byli Szwedami. Zapewne różne były motywacje, dla których mobilizowali swoje pióra dla króla szwedzkiego; na pewno do ważniejszych nalezal mecenat królewski oraz solidaryzowanie się z protestantami, w interesie których wystçpowat Gustaw Adolf.

Wkrótce po zdobyciu Rygi w mieście tym wyszła obszerna prozatorska relacja o tym wydarzeniu. Autorem byl zapewne jakiś miejscowy humanista, który staranną laciną opisał desant oddziałów szwedzkich. Do utworu dołączono mapę, na której wyraźnie widać, że miasto zupelnie bylo pozbawione obrony przez Polaków. Wladze Rygi argumentowaly poddanie siç whadzy Gustawa Adolfa obojętnością ze strony "Sarnatów”. Między innymi tego dotyczy utwór $O z d o b$ ) ciu $R$ ygi z $1627^{\text {ly }}$, w którym zamieszczona została polemika między ryżanami a hetmanem Krzysztofem Radziwitlem.

\footnotetext{
'Zob. B. Plinius, op. cit., k. B +r'.

in Zob. De exprenatione ciritatis Rigensis... epistolac IIII. [Rigac| 1627.
} 
W okresie wojen z Polską najpłodnicjszym poeta piszącym o sukcesach Gustawa Adolfa byl Joannes Narssius. Nieliczni badacze odnotowujajego Gustaride, jeden z kilku podobnych eposów opiewających czyny Gustawa Adolfa w Rzeszy, które to eposy ukazały się w latach trzydziestych XVII wieku'". Trzy pierwsze księgi Gustavidy Narsiussa wyszly w 1632 w Kolonii, czwarta w 1634. Sprawa polska zostala w nich potraktowana marginalnie, tematem utworu są bowiem zmagania z cesarzem. Oprócz tego eposu Narssius oglosił sporo muiejszych objçtościowo zbiorów. Jednym z najwcześniejszych są jego Poemata Septentrionalia wydane w Hamburgu w 16242"1. Rok później w Rydze wyszedl poemat Riga devicta ${ }^{21}$, w epicki sposób odmalowujący zdobycie tego miasta. Jak przystało na tego typu dzieła, autor zaręcza, żc będzie pisal cala prawdę i tylko prawdę:

Nonfabulam confictan exhibe, sed rei vere gestae veram et genninam historiam, cuins argumenum et partes singulas habe partim ex relatu magnatum, alionmque testium oculatorum, partim exa Senatus Rigensis eleganti Epistola Historico-Apologetica ad illustrissimum principem Radzinilinm, quam quidem ante triennimm editan hactenus silentio sno comprobarant ipsi Poloni?

Mimo że w późniejszych częściach przedmowy Narssius powohıje się na Wergiliusza, a wiçc sugeruje, że i jego natchnęła podobna do wenuzyjskiej muza. jego program poetycki jest zbieżny z pomyslami innych poetów piszących wcześniej i później podobne heroica, na przykład wspomnianego juz Bojera czy Samuela ze Skrzypny Twardowskiego: historyczne opisywanie faktów wierszem. Oczywiście, dodajmy od siebie, faktów zgodnych z interesem strony, którą wspierał swym piórem poeta.

Podobuy zatem charakter co Riga devicta ma późnicjszy o kilka lat utwór Mera liberata ${ }^{23}$ o bitwie pod Gniewem pod koniec września 1627 roku, do którego dodano szereg drobniejszych wierszy, między innymi o zdobyciu Braniewa, spustoszeniu Fromborka czy poddaniu Malborka. Wśród tych wierszy znajdıją się również konceptystyczne drobiazgi, jak cykl prozopopei armaty zdobytej przez Radziwillów i odzyskanej przez Szwedów po zdobyciu Birz ${ }^{2+}$.

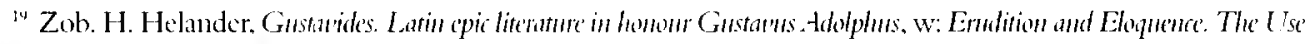
of Latin in the Commtries of the Baltic Sea (1.500-1800). wyd. (O. Merisalo, R. Sarasti-Wilenius. Helsinki 20113, s. 112-125.

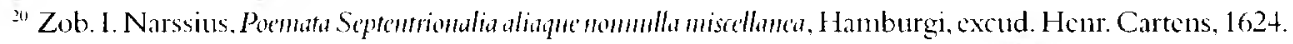

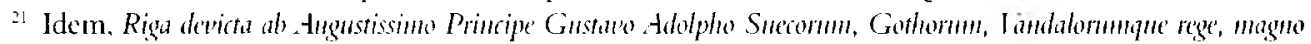
principe Finlandiac, duce Esthoniae, Careliaeque, net non Ingriar demime, cte etc carmine heroico descripta, Rigac Livonum, excud. Gerh. Schröder, 1625.

$\because 2$ Ibidem.

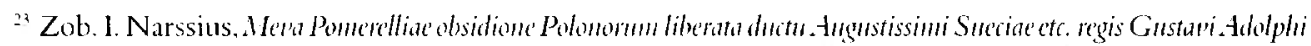

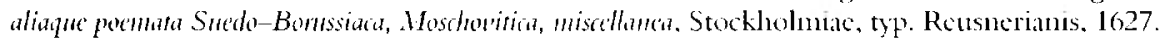

-4 Ibidem, s. 93 :
}

Tomentormin matuperatorum prosopopocia

1. Machina capta fui. Se lyomm solpit is ipse

Qui napuit. Bursuc Byra a peregit opus. 
Krzysztof Radziwill nieraz pojawia siç w propagandowych wierszach szwedzkich. Szeroko rozpisywano się o barbarzyńskich obyczajach Polaków (choć właściwie nowa powinna być o Litwinach), którzy internowali w roku 1625 posłów szwedzkich. Narssius poświęcil temu wydarzeniu kilkadziesiąt heksantrów w utworze o wielce znaczącym tytule Fides et lumanitas Polonica ${ }^{25}$. Nieludzkość — inhmmanitas — poddanych króla polskicgo byla zresztą dość częstym toposem u Narssiusa i innych poetów. Przywoluje go między innymi Joanmes Breverus, autor poenatu napisanego po podpisaniu rozejmu w Sztumskiej Wsi ${ }^{20}$.

Lektura większej liczby tekstów szwedzkich pozwala wychwycić inne toposy lub obrazy. W wielu poematach spotykany opis husarzy, na przyklad w poemacie o bitwie pod Gnicwem, zapewne też dlatego, że Gustaw Adolf omal nie postradal zycia w walce z jednym z nich. Narssius rozwija ten motyw w wydanej niedlugo później tragedii Custanus sancins ${ }^{27}$, w której chóry wodzów, obywateli i matron szwedzkich doradzaja królowi, aby chronil swoje ceme zycie i unikal osobistego zaangazowania w walkę?. Jak wicmy, Gustaw nic posluchal tych rad, ponosząe śmierć w bitwie pod Lïtzen.

Innym takim motywem jest przypominanic przez pisarzy pozostających na shuzbic szwedzkiej tradycji jagielloniskich. Breverus w swoich Induciad uszczypliwie zauwaza, że pokonany przez Szwedów Wladystaw IV to Jagicllonida - ale jakze odmienny od swoich przodków. Te jagiellońskie alızje żywe będą w lacińskiej poezji szwedzkiej jeszcze na początku XVIII wicku. W rękopiśmiennym zbiorze wierszy Clades Saxonormm z 170)1 jeden z wierszy zaczyna się tak:

\section{Larna Lagellonidi, Moscon sed Name tyramo}

Nominc fatali dadis origo fuit ${ }^{2 s}$.

Poeci szczególnie upodobali sobie motyw ucieczki Polaków z pola walki: husarzy, chwicjnych Kozaków, wodzów. Motyw ten zwykle wystẹpuje po przedstawieniu polskiej pychy i przeclıwalek. Armia polska, zdaniem Narssiusa czy Breverusa. tylko pozornie jest silna, w gruncie rzeczy rozpierzcha się po dluzszym starciu.

\section{Ininste capta hand roni defendere By y $^{\prime}$ as}

Firla fin Domino, instalue praeda redi.

III. Hamms eram Sucommm Patulo quac me ore domabat At reachad Suenes Byza mesella remir.

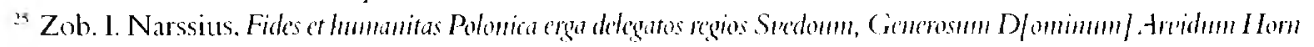

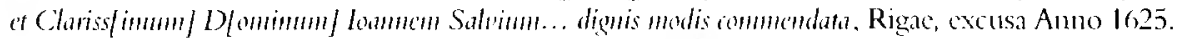

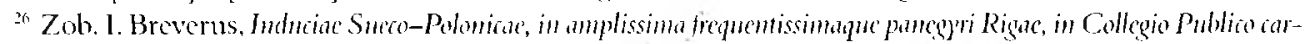

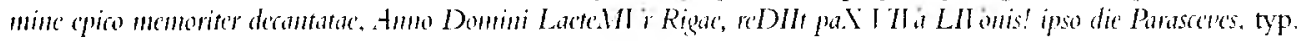
Gerlı. Sclıröder [1635; data podana w chronostychu|.

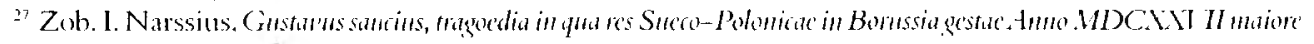
ex ponte enaramtm, I Iafuiac, typ. Salom. Sartorii, 1628

in Miscellanea poetica Latina, rẹkopis Biblioteki Unwwersyteckicj w Uppsali Carolina Rediviva (dakj: Ups.), sygn. R 391 . 
Antypolskie wiersze pisali protestanci, nic więc dziwnego, ze Polaków, w tym Litwina i kalwinistę, Krzysztofa II Radziwiłla, przedstawia się jako zagorzalych papistów, dążących do podbicia Szwecji i do zburzenia pokoju. Już we wczesnym wierszu Narssiusa, epitafium Karola LX, spotykamy się z tym motywem: ,. [Karol] zbrojnie obronil pokój, który naruszyli Polacy, uchronil też Szwecję przed papieskim jarzmem, w którym tkwi Zygmunt III"?"'.

Knowania papieża, l liszpanów i Polaków (w różnych kombinacjach) przez dziesiątkı lat wspierały szwedzką literatırę propagandową. Sami Polacy nie daliby rady Szwedom, dlatego zwracają się o pomoc do cesarza:

\section{Cogere wit SUEONES ad Papae iusa POLONUS Sed satis hand fidit riribus ipse suis ${ }^{30}$.}

Szczególnie podtą rolę mają do odegrania jezuici. We wspomnianej tragedii chór wodzów roztacza czarną wizję triumfujących Polaków oraz "Lojolitów”:

\section{Spirabit amma. Flamina addet ac faces}

Intws Megaeran gens, foris Lesum gerens.

Te motywy znajdą później oddźwięk w innych utworach europejskich, czasami nawet w tych, których autorzy zupełnie nie interesowali się konfliktem polsko-szwedzkim. Oto przyklad.

W 1636 ukazal się w Paryżu elegancki, choć niedużych rozmiarów druk, na dobrym papierze i w ladnej oprawie. Na stronic przedtytulowej jest miedzioryt: heros z garścią piorunów w prawicy i z wieńcem laurowym na głowie dosiada orla. Głowa ptaka marnie zwisa, u stóp zwyciçzcy leżą sztandary. Nic są to jednak sztandary polskie, i orzel też nie jest polski, lecz cesarski. Poemat heroiczno-polityczny, jak to zostalo ujęte na karcie tytulowej, zostal poświęcony drugiemu etapowi wojny trzydziestoletniej i nosi tytul Piormu u' orta, czyli Gustau'a

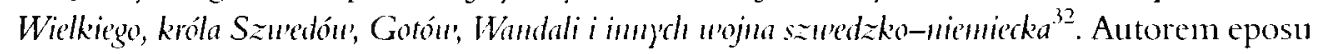
w dwunastu księgach (czy też w dwunastu uderzeniach, bo każda księga określana jest jako kolejuy ictus) jest francuski hugenota, Evurtus Jollyvet. Autor pisze o podboju Pomorza, Śląska, marszu w gląb Rzeszy; Polska wlaściwie go nie interesuje, chyba że jako tło i dodatek. $Z$ tego powodu jest to cickawe, bo Jollyvet sięga po toposy, które stanowily oś ideologiczną utworów Narssiusa: tu są jedynie klockami, którymi obudowuje się główną narrację. Na początku Ictus septimi stęskniona za Gustawem królowa Elconora jest wysławiana w kolejnych miastach, przez które podąża król (Berlin, Drezno itd.). Ta sama tęskniąca i martwiąca się Eleonora jest główną bohaterką wspommianego wyzej dramatu Narssiusa Gustauus sancius.

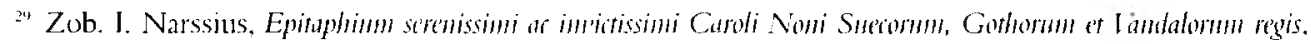
w: idem. Pocmata Seprentriomalia.... op. cit.. k. B 2 I'.

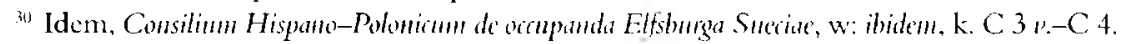

3 I. Narssius, Gustanus samius..., s. 63.

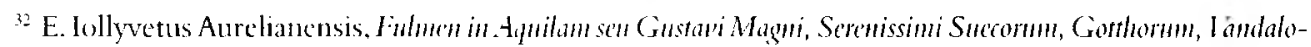

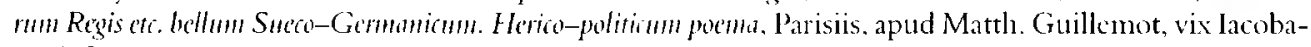
ea, 1626 .
} 
Polacy, jak wcześniej Moskale i Duńczycy, przewijaja siç tylko przez pierwsza księge książki Jollyveta, są epizoden na marģinesie zmagań z cesarzom. Autor umieścil ich dlatego. że nie mógl pominąć w swojej narracji wojny z Rzeczapospolitą, ale też aby pokazać, że Gustaw Adolf radzil sobic jednocześnie na dwóch frontach przeciw połaczonym dwón orłom:

Ferdinandus opes, victus, tormenta, caternas

Pracbuit adversus Succos, dum bella Polonis

Instus et admisso regui pro iare morebas,

I idimus hic doplices Aquilas centumtibus amcis ${ }^{33}$.

Pokonany Ferdynand dostarcza posilki, pęta, rzesze wojsk, gdy sprawiedliwie prowadziłeś wojny w inię prawa, gdy Polacy wystapili przeciw królestwu. Widzimy tı dwa orly z wojowniczymi szponani [thum. J. N.].

Ale, jak zaznacza Jollyvet, Gustaw skutecznic zagrozil Zygmuntowi i sprawa zakończyla się pozytywnie dla Szwedów, a nieszczęśliwie dla .niegodziweģo cesarza”.

Motywy obecne w poematach drugiej wojny polsko-szwed zkicj (1626-16.34) żyly w poczji lacińskicj jeszcze co majmniej przcez kilka dziesięcioleci. Najprawdopodobniej z utworów Narssiusa korzystał anonimowy autor rękopiśniennego epicedium Karola X Gustawa. Wymienione są w nim wszystkie ważnicjsze bitwy stoczone przez Gustawa Adolfa. Karol X jawi się zatem jako spadkobierca swojego dziada:

Tenderet in vestris, proh! Regma Bonssica terries

Qua primmm t'alidis surgit Pilania muris.

Ut Bromberga statim I ictori cederet, at mox

Fida Elbinga parnm Dominis, Mariaeque dicatum

Castellum et celebris longe mumimium Me'ace,

Diraniaeque domus, genitor quas I istula potat

Utque Duces patriis depustes sedibus arri

Sertaret dextra annctisque insignia tandem

Redderet exultans animac contemptor at ali

Sanguinis antiqua pro libertate ruentem

Quem fudit rosetis simul se miscuit astris.

Wszystkie wymienione przeze mnie teksty są dzisiaj wlaściwie martwe: temat, który poruszają, dawno temu juz się zdezaktualizowal. Ale nawet jeśli ktoś interesuje się wojnami XVII wiekı, chętniej skorzysta z ówczesnych dokumentów niż z relacji poetyckich. Poezja wszak, z racji swojego języka, nie może być gwaranten rzetelności przekazu. Trzecim, decydującym powodem, dla którego dziś się nie czyta Carolomachii,jest lacina i kod przekazu, który wymaga dobrej orientacji w literaturze antycznej oraz nowożytnej. 
Jednakże lektura epiki propagandowej polsko-szwedzkiej, choć czasami, delikatnie mówiąc niezbyt porywająca, nic jest bezcelowa. Przede wszystkim należy odsunąc zarzuty, stawiane poezji jako źródlu historycznemu. Lektura i zestawienie tych tekstów ze sobą i umieszczenie ich w odpowiednim kontekście buduje obraz tantego fragmentu przesztości nie gorszy niż oparty na przykład na korespondencji dyplomatycznej lub rachunkach za proch. Tyle że jest to obraz inny.

Można w tych utworach prześledzić tworzenic się mostów między historiografiąa a poezja epicką. Jeśli potraktujemy je jako historiografię, jak na dłoni ukaże się modahóśc ich struktury fabularnej, zwlaszcza gdy zestawimy ze sobą teksty obu stron. Poeci z obu stron stosują te same chwyty fabularne, różnice polegają tylko na róznicy ich talentów.

Stąd już tylko krok do zastosowania tej operacji wobec tekstów niepoetyckich. Od polowy lat trzydziestych Szwedzi publikowali teksty traktatów pokojowych między ich królestwem a Rzecząpospolitą lub Gdańskiem. Początkowo ukazywaly się one w wersji niemieckiej i tacińskiej, następnie po polsku i po szwedzku. W omawianym wyżej poemacie Breverusa punkty zawartego rozejmu zostaly ubrane w formę heksametru. Można wszakże postawić pytanie, czy drukowanie petnych wersji dokumentów było zupełnie neutralne, mniej nacechowane niz przedstawienie ich w formie poetyckiej?

Nie mamy żadnych świadectw tego, że autorzy piszący z jednej strony dla króla polskiego, a z drugiej dla szwedzkiego znali nawzajem swoje utwory. Prawdopodobnie tak, chociaż ich teksty nie są polemikami i nic spotkamy się w nich z bezpośrednią refutacją lub kontrrargumentacja.

Można przypuszczać, że międzynarodowa propaganda polityczına w basenie Morza Baltyckiego tylko po części jest rezultatem świadomych i celowych działań obu kancelarii królewskich. Bez uwzględnienia tych tekstów tylko częściowo da się zrozumieć fenomen polskojęzycznych eposów XVII wicku Samuela Twardowskiego oraz Waclawa Potockiego oraz pomniejszych autorów, jak Marcin Kuczmarewicz, Gabriel Krasiński czy Samuel Leszczyński. 